Chovancova, B., Hudcovsky, J., \& Kotaskova, A. (2019). The Impact of Stocks and Bonds on Pension

Fund Performance. Journal of Competitiveness, 11(2), 22-35. https://doi.org/10.7441/joc.2019.02.02

\title{
THE IMPACT OF STOCKS AND BONDS ON PENSION FUND PERFORMANCE
}

\section{- Bozena Chovancova, Jaroslav Hudcovsky, Anna Kotaskova}

\begin{abstract}
Stocks and bonds represent the two most common assets in pension fund portfolios. For both pension fund participators as well as pension fund administrators it is necessary to examine the impact of stock and bond markets on the pension fund. This paper investigates the connection between stock, and, respectively bond market and pension funds. The relationship between the pension market and representative stock and bond market indexes was confronted. Research data based on pension statistics from the Organisation for Economic Co-operation and Development were included in our research. A stronger impact was shown of the bond market on pension fund performance. The paper is divided into 5 chapters. In the first chapter, we introduce theoretical approaches along with essential knowledge in terms of a deeper analysis of research problems. The second chapter focuses on a literature review, with the third detailing the methods and methodology of research. The fourth chapter focuses primarily on achieving and interpreting the results of research in the context of the set objectives. In the fifth chapter, the achieved results are aggregated in the form of particular recommendations formulated after studying the issue.
\end{abstract}

Keywords: asset portfolio, bond, stock, pension fund

JEL Classification: G11, G23, J32

Received: June, 2018

1st Revision: October, 2019

Accepted: October, 2019

\section{INTRODUCTION}

Private and public pension schemes are currently facing several challenges (Mačí \& Valentová Hovorková, 2017; Vychytilová, 2015). The economic crisis has led to a reduction in public revenues and thus the ability to ensure adequate living standards of their citizens at old age through pay-as-you-go pension schemes. This development naturally generates an increased space for the empowerment of the private pension administrators in providing retirement income. The common and the greatest challenge for public and private pension schemes, however, is the negative demographic trends currently present in almost all advanced economies (Schulmerich et al, 2014; Rimashevskaya et al., 2017; Sinicakova et al., 2017). Population aging leads not only to an increase in the retirement age population in proportion to the (employed) working age population, but also to an increase in the number of years spent in retirement. One risk to the sustain- 
ability of pension schemes is the policy of low interest rates, which together with the slow pace of economic growth reduces the scope for potential appreciation of retirement savings (Sinicakova \& Gavurova, 2017). In order to ensure adequacy, the study of pension compensation represents a basis for a thorough analysis and a review of the current pension systems (Yao, 2014). The analysis of pension systems is involved in a special section of economy and the so-called pension economy. A principal category in the study of economics is represented by examining pension income (Zou et al, 2016). A pension can perform two basic tasks. Firstly, it generates income for individuals based on their previous economic activity (Wang, 2016; Androniceanu, 2017; Papik, 2017). Secondly, a pension can be seen as a type of insurance based on long-term contracts between savers and pension administrators (Hainaut, 2014; De Hann, 2016; Alda, 2017; Wiafe et al., 2017). The pension economy aggregates knowledge of microeconomics, particularly in decision-making and risk perception, based on individual preferences along with efforts to maximize usefulness. The pension economy is also based on principles of macroeconomics, and it analyses the impact of the pension system on the capital market, labour market as well as the fiscal impact of the pension system on public finances (Gavurova et al., 2017; Ząbkowicz, 2016; Bartram, 2016; Fabuš, 2017; Farias, 2017). The above characteristics indicate that the pension economics deals with issues of the allocation, recovery and redistribution of scarce resources throughout the life cycle of a saver with implications on the macroeconomic and microeconomic perception of the state guaranteed pay-as-you-go pension system and private pension funds (Thomas et al, 2014; Sun et al., 2017; Tao et al., 2017; Vassallo et al., 2017).

In this paper, we introduce the relationship among pension funds with selected stock and bond market indexes. We have chosen stocks and bonds as representing the majority assets of portfolios of pension funds across countries. We use data from the Global Pension Statistics Database of the Organisation for Economic Co-operation and Development, which summarises data from all the 35 member countries. As for the selected benchmarks in our research, broadly diversified indexes were used: the Standard \& Poor's 500 Index, the Euro Stoxx 50 Index, the Morgan Stanley Capital International Pacific Index, the Morgan Stanley Capital International World Index, Standard \& Poor's 500 Bond Index, the Bank of America Merrill Lynch Index, the Bloomberg Barclays US Aggregate Bond Index, and the Big World Index.

\section{THEORETICAL BACKGROUND}

The theoretical basis of the analysis is established on the authors' knowledge of the effective operation of interim pension schemes. This system converts it into a funded system of financing based on the pension fund. The authors have also noted a different fund management strategy in the case of a defined benefit or a defined contribution pension plan.

Gruber (2012) points out the issue of risk sharing and redistribution of resources in different types of pension schemes. According to the author, funded pension systems face several issues, particularly the risk of inadequate compensation ratio between wages and pensions and the associated investment and interest rate risk. For the stability of the pension system, mainly the political risks arising from the nature of the four-year political cycle are critical. The greatest risk is represented by a demographic decline not compensated by additional measures. Gruber 
defines an optimal degree of risk sharing as a dependent variable, from which value derives from an increase in pension savings, for instance equity and pension funds as a variable dependent on the development of the capital market, depending on the allocation of resources. When transferring capital across generations through compulsory contributions to a funded system, the profit generation $t+1$ is multiplied by the value of the marginal product of capital. Consequently, the profit generation $t+1$ is higher than the profit generation $t$. The PAYG system allows the reallocation of funds within a generation, thereby sharing the risk of integration when the resources are limited, but the so-called Pareto efficiency principle also comes into pla, according to which any individual or a group of individuals cannot obtain sufficient resources without funding cuts of another individual or a group. The only option is to increase the total volume of resources through additional revenues.

Hertrich (2013) highlights the positive impact of a broadly diversified investment portfolio managed by pension trustees on the capital market. Therefore, the portfolio of the pension fund has to be formed by a mix of fixed interest assets and interest sensitive assets. The volume of bonds exceeds the volume of shares, especially due to the particularity of the pension saving and investing scheme. Exclusive of bonds and equities, pension assets should be allocated to alternative investments as well. Hertrich (2013) supports the investments of pension funds into commodities, the processing of which underlies an appropriate risk diversification. According to the author, investments in physical assets such as the real estate have an impact on the efficiency and performance of the pension fund in the medium- and long-term horizon. The short-term impact on portfolios of physical assets of pension funds stems from the nature of the unproven investment. Hertrich (2013) recommends introducing a system of guaranteed minimum and maximum income. Revenues in excess of the guaranteed bandwidth would serve as a hedge portfolio in the case of a negative development of the portfolio in the future.

According to Mitchel et al. (2016), the role of regulators is very important. The possibility of estimating the development of the pension fund sources is very important in making a decision on an investment. A stable flow of funds enables the administrators to choose an efficient strategy with regard to the risk specialization of the fund. The payment of funds may be supported by the possibility of accurately estimating future entitlements with regard to the retirement age limit.

Devolder et al. (2013) also highlight differences in investment strategies with defined benefit as well as defined contribution pension plans. According to the authors, the risk of higher volatility is particularly associated within defined contribution pension schemes. Therefore, the asset portfolios of pension funds are more hazardous than those of defined benefit pension plans. These types of pensions bring a higher risk for participants concerning future pension. The investment strategies of pension funds are in the case of a defined benefit scheme very conservative. The asset portfolio is dominated by bonds. The risk of a defined benefit plan bears a pension fund manager, who must ensure the agreed financial performance for the participants of the pension scheme. Pension plans with the defined benefit face a greater risk due to population aging than the contribution pension plans.

In the preparation and management of the pension fund, managers must take into account the clients' attitude towards risk. According to Bajtelsmit (2015), pension savers can be divided into three groups. The first group of clients is risk-averse savers. A risk averse is such a pension 
scheme participant, who prefers minimizing the risk of a potential loss. In other words, among various investments giving a similar expected return with a different level of risks, the participant prefers the one with the lower risk. The second group is risk-seeking clients. In this case, the pension scheme participant prefers a higher appreciation potential even at the cost of higher risks from a similar investment. The third group consists of risk-neutral clients. For the pension savers, it is a case of a neutral preference among different types of securities in the pension fund's portfolio. The pension fund managers invest in a broad portfolio of assets, taking into account the different preferences of pension savers. The author analyses the relationship between information and access to the risk. The information helps reducing the cost of decision-making. In the case of pension funds, a better access to information leads to a more efficient decision-making on the allocation of pension savings in line with the pension fund's investment strategy.

Clements et al. (2014) emphasize the particularly positive impact of the employee pension funds on the long-term sustainability of the pension system. According to the authors, the main challenge for the pension system is to ensure the protection of citizens' savings and the adequacy of pension entitlements consistent with the pension system's revenues and expenditures. The essence of the transformation of the pension system into a system based on occupational pension funds is the reallocation of funds linked to a more funding pillar, respectively, part of the privatization of mandatory pension schemes. An alternative could be the introduction of a supplementary pension scheme under the administration of a particular employer or a group of employers. For the effective functioning of an occupational retirement pension scheme, basic definitions must be formulated - compulsory or voluntary participation in the scheme, the percentage to be paid for the contributions as a part of the pension plan, retirement age or a minimum number of years. An important issue in this area is also the taxation of the benefits paid and the method of reimbursing the accumulated funds.

Bürtler (2002) emphasizes the reform of the old-age insurance system. According to the author, the reform of the old-age insurance is one of the persistent problems of society. A key policy issue in the ongoing debate is the flexibility to better meet with the different individual needs of pensioners. The paper argues that more flexible retirement options can have a significant impact on both the solvency of the pension system and the distribution between and within generations.

Schulmerich et al. (2014) highlight the education factor as a key variable affecting the future amount of a pension. Higher education leads to more effective strategies for a pension saving planning. According to the authors, in the pension economics, it is important to ensure that there exists a choice between defined benefit and defined contribution plans. The authors point to the positive impact of a mandatory participation in the funded system on the stability of pension savings. In the case of a defined contribution scheme, it is important to ensure an individual investment strategy for highly qualified employees in accordance with their investment preferences. The main task of a defined benefit pension scheme is to provide a minimum guarantee of the pension provision and is, therefore, more appropriate for less-skilled workers in accordance with their investment profile. According to the authors, it is important to simplify and transparently propose individual pension plans. The investment profile and focus of the individual pension funds should concentrate on the differences between the market risk assets. Each pension 
plan should include basic types of pension funds ranging from less risky bonds to the riskier equity funds. Investment managers should also offer expanded investment opportunities designed especially for sophisticated pension savers. In the case of occupational pension funds, it is important for the stability of the pension system to ensure the protection of pension savings from the threat of the employer's insolvency. It is therefore important to regulate investments in own securities in the case of pension plans established by employers or interest groups and employers. Any effective pension schemes are characterized by appropriate regulation defining the minimum requirements necessary for the payment of the pension and the amount of the annuity that is counted towards the accumulated funds and the estimated life expectancy.

Vogel, Ludwig, Borsch-Supan highlighted (2017) the role of population aging. The authors take into account the three most demographically old European nations - France, Germany, and Italy - to focus on the three important channels of adaptation to reduce the detrimental effects of aging in these countries. These channels are investing abroad, creating endogenous human capital and increasing the retirement age. Their quantitative finding is that creation of endogenous human capital combined with the increase in the retirement age has strong implications on the economic aggregates and welfare. It mainly affects the open economy (Ohanyan \& Androniceanu, 2017). These adjustments reduced the maximum welfare losses of demographic changes in the households by about 2.2 percentage points in 2010, in terms of the consumption equivalent variation.

Often, the authors are confronted with concerns stemming mainly from demographic changes in this area, which may disturb the market balance, pensions and investments. Among the measures proposed, most commonly included measures are increasing the statutory retirement age, strengthening the position of private pension managers or policies promoting employment and active participation in the capitalisation pension system. On the contrary, the authors differ in the concept and the position of the various types of pension schemes and pension plans. In our opinion, the most important lesson is a guide to the proper setting of the pension system, including the relationship between the interim and the funded pillar. Important areas are those trying to find a way to apply theoretical knowledge to specific outputs in the form of quantifying the impact of macroeconomic and microeconomic variables on the pension portfolio efficiency.

\section{RESEARCH OBJECTIVE AND METHODOLOGY}

The designated methodology is aimed at a comparison of the pension funds in the selected countries with several benchmarks representing the global stock market, respectively global bond market indices. This analysis can answer the arisen questions such as the pension funds success in management of the entrusted funds in relation to the average market indicators. By using the econometric modelling at the same time, we try to estimate the impact of each independent variable - in this case equity, respectively bond indices to assess the pension funds. In this analysis, directly measured/achieved values are excluded. Also, the intraday changes of index values are examined, correspondingly the value of pension funds.

The first part of the analysis is focused on the interaction between the selected equity index and an average recovery of the pension funds managed by different asset management of companies 
throughout the Organisation for Economic Co-operation and Development member countries. The selected stock indices, meaning the independent variables, come from the Standard \& Poor's 500 Index, the Euro Stoxx 50, the Morgan Stanley Capital International Pacific Index, and the Morgan Stanley Capital International World Index.

The essential equation of the first regression model is as follows:

$P F=\beta_{0}+\beta_{1} S P+\beta_{2} E S+\beta_{3} M S P+\beta_{4} M S W$

where the involved variables are:

$\mathrm{PF}$ - the dependent variable: the pension funds;

$\beta_{0}$ - intercept: constant value;

$\beta_{1}$ - the estimated regression coefficient of the first independent variable;

SP - the first independent variable: the Standard \& Poor's 500 Index;

$\beta_{2}$ - the estimated regression coefficient of the second independent variable;

$\mathrm{ES}$ - the second independent variable: the Euro Stoxx 50 index;

$\beta_{3}$ - the estimated regression coefficient of the third independent variable;

MSP - the third independent variable: the Morgan Stanley Capital International Pacific Index;

$\beta_{4}$ - the estimated regression coefficient of the fourth independent variable;

MSW - the fourth independent variable: the Morgan Stanley Capital International World Index.

In the second part of this research, an impact of the dominant component of the portfolio under management by pension administrators, namely bonds, is analysed to evaluate the pension assets. They involve the assets with fixed income compared with the shares having a lower risk but also lower potential returns. Yet, they are an attractive option for allocating funds under management for the individual, not just the specialised bond of the pension funds. As it is stated in the previous section, we will try to assess the impact of selected variables representing the bond market to evaluate the pension funds through econometric modelling. In the analysis, we observe intraday changes in the selected exogenous and endogenous variables. As the independent variables, the broad global bond indices compiled by respected investment enterprises are selected. For the needs of our model, we chose four bond indices, namely the Standard \& Poor's 500 Bond Index, the Bank of America Merrill Lynch Index, the Bloomberg Barclays US Aggregate Bond Index and the Big World Index.

The elementary equation of the second regression model is as follows:

$P F=\beta_{0}+\beta_{1} S P B+\beta_{2} M L+\beta_{3} B B+\beta_{4} B W$

where the involved variables are:

$\mathrm{PF}$ - the dependent variable: the pension funds;

$\beta_{0}$ - intercept: constant value;

$\beta_{1}$ - the estimated regression coefficient of the first independent variable;

SPB - the first independent variable: the Standard \& Poor's 500 Bond Index; 
$\beta_{2}$ - the estimated regression coefficient of the second independent variable;

$\mathrm{ML}$ - the second independent variable: the Bank of America Merrill Lynch Index;

$\beta_{3}-$ the estimated regression coefficient of the third independent variable;

$\mathrm{BB}$ - the third independent variable: the Bloomberg Barclays US Aggregate Bond Index;

$\beta_{4}$ - the estimated regression coefficient of the fourth independent variable;

BW - the fourth independent variable: the Big World Index.

\section{RESULTS AND DISCUSSION}

There are the both models analysed in this section.

\subsection{The first regression model}

For the explored period, the largest average annual appreciation of the Standard \& Poor's 500 Index is at the level of $8.8 \%$, while the smallest variance can be observed while assessing the Euro Stoxx 50 Index. When compared with an average annual appreciation of the pension funds within the Organisation for Economic Co-operation and Development member countries, which amounted to $2.34 \%$, it can be concluded that all the selected indices recorded a higher average appreciation than the pension funds in the surveyed countries.

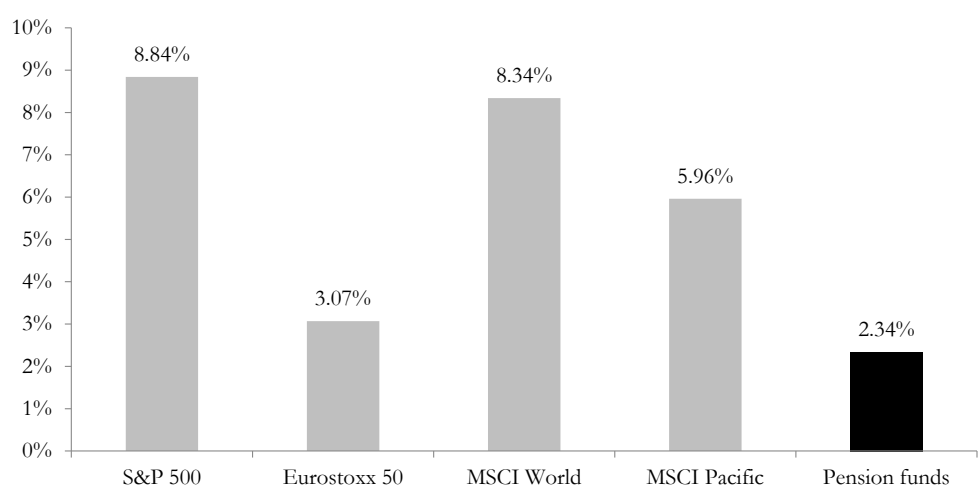

Fig. 1 - The average annual yield of the selected market indices and the aggregate value of the pension funds from 2005 to 2015. Source: The Organisation for Economic Co-operation and Development data

The first model equation is as follows:

$P F=26.8545+0.257954 S P-0.17554 E S+0.61093 \mathrm{MSP}+0.113586 \mathrm{MSW}$. 
Tab. 1 - Summary of the first regression model. Source: own elaboration

\begin{tabular}{|l|r|r|r|r|c|}
\hline indicator & \multicolumn{1}{|c|}{ coefficient } & standard error & t-test statistics & \multicolumn{1}{c|}{ p-value } & $\begin{array}{c}\text { statistical } \\
\text { significance }\end{array}$ \\
\hline $\begin{array}{l}\text { constant } \\
\text { value }\end{array}$ & 26.8545 & 0.555499 & 48.343 & $<0.00001$ & $* * *$ \\
\hline SP & 0.257954 & 0.0202 & 12.7701 & $<0.00001$ & $* * *$ \\
\hline ES & -0.17554 & 0.007318 & -23.9874 & $<0.00001$ & $* * *$ \\
\hline MSP & 0.61093 & 0.019367 & 31.545 & $<0.00001$ & $* * *$ \\
\hline MSW & 0.113586 & 0.035319 & 3.216 & 0.00132 & $* *$ \\
\hline
\end{tabular}

Legend - statistical significance: * $-(0.05 \dashv, \vdash 0.01)$; $^{* *}-(0.01 \dashv, \vdash 0.001) ;{ }^{* * *}-(0.001 \dashv, \vdash 0\rangle$

Looking at the results, we can conclude that there is detected a positive impact expressed through the correlation coefficient with the three of the four variables of interest. The coefficient representing the independent variable of the Euro Stoxx 50 index reaches a negative value. This results in a devaluation of the pension funds by $0.17 \%$, if the value of the Euro Stoxx 50 index increases by one percentage point. From an analytical point of view, this outcome can correspond to a small presence of the European equities in the total portfolio of the pension funds. The other variables involved in this analysis reach the correlation coefficient higher than 0 , which represents a confirmation of the hypothesis regarding the positive impact of the independent variables on the dependent variable associated with the pension funds. It is quite interesting that just only the Euro Stoxx 50 index reaches a negative estimated regression coefficient. Also, there is to note the size of the assigned coefficients. The highest one is related to the Morgan Stanley Capital International Pacific Index, whilst the lowest one to the Morgan Stanley Capital International World Index. Their ratio is approximately about six which means the first one bears a six times more powerful influence on the dependent variable. A constant value bears a huge coefficient that is more than ten times higher than the maximum regression coefficient of the independent variables.

Taking the value of t-statistics into consideration, where the significance level $\alpha$ through trying to prove that we have tested the relationship is not random and that is whether we can confirm adequate records in favour of statistical significance of all the variables of interest. The values of the t-test statistics lie outside the range from -1.96 to 1.96. This means that we can reject the zero hypothesis $\mathrm{H}_{0}$. Basically, the detected result is that the measured coefficients are different from zero, and thus they are statistically significant.

If we have a look at the p-values of the independent variables, it is apparent that the previous findings are correct. The p-value indicator allows us to reject the hypothesis regarding the statistical significance of the variables. Hence, the alternative hypothesis can be adopted in general. The aggregated data show that all the selected indicators demonstrate a lower level for the p-value than the confidence level $\alpha=0.05$, allowing us to reject the zero hypothesis $\mathrm{H}_{0}$. It can be concluded that a given variable is statistically significant to explain the dependent variable representing the pension funds indicator.

The coefficient of determination $\mathrm{R}^{2}$ achieves a relatively high value of $94.08 \%$ in the first model. An economic interpretation of this result indicates that the suggested model explains more than 
$94 \%$ of the variability of the dependent variable concerning the pension funds. Another important coefficient of determination is adjusted $\mathrm{R}^{2}$. In this case, it reaches a value of 0.940697 , which can be also considered high, indicating the statistically significance of the model.

The first model value of the F-test statistics reaches a level of 10,342.37 The critical value for this model is a level of 2.996. Therefore, the valid F-test fulfils this requirement, as 10,343.37 is higher than the critical value of 2.75297 . With reference to the testing process for the statistical significance of the coefficients of the regression model, we can conclude that the independent variables are jointly statistically significant.

According to this interpretation, it can be summarised that the proposed model confirms the assumed relationship between the change in a value of the equity indices and the development of the pension funds managed by asset management companies in the member countries of the Organisation for Economic Co-operation and Development. All the variables studied in this analysis achieve statistical significance. In this model, the coefficient of determination $\mathrm{R}^{2}$ as well as its adjusted version have reached a relatively high level, even during the execution of the t-test and the F-test, sufficient evidence in favour of the statistical significance.

\subsection{The second regression model}

The centre of focus of the second regression model is the bond market, represented by the selected bond market indices. The average annual evaluation of the selected indices ranges from $3.66 \%$ to $5.40 \%$. Compared to the share index, this figure is higher at a level below average of appreciation. However, the entire examined bond index managed to overcome the average performance of the stock index Euro Stoxx 50 during the observed period. Between 2005 and 2015, it achieved an average annual appreciation of $2.34 \%$, a result which encompasses with average performance of the pension funds within the Organisation for Economic Co-operation and Development member countries. Thus once again it can be said that the actual performance of the bond market outperformed the specialised pension funds.

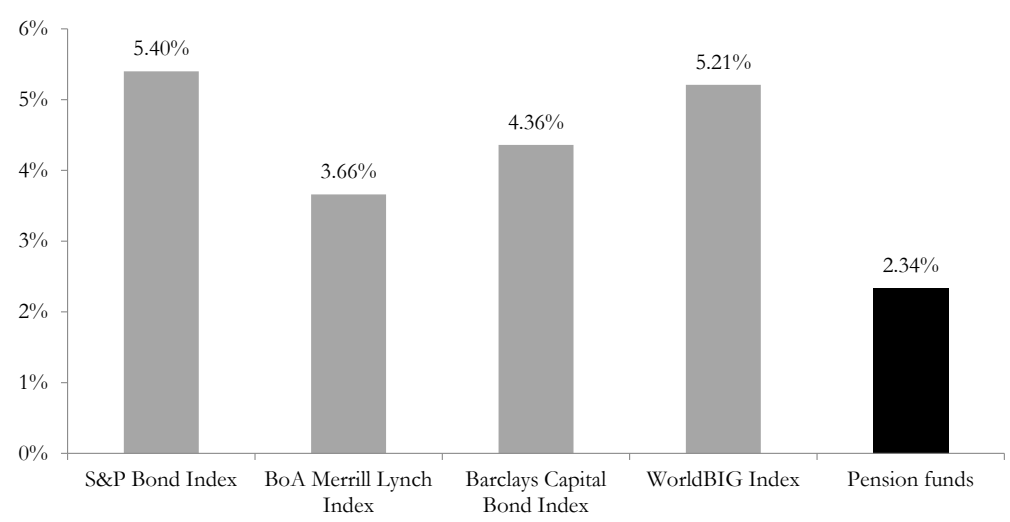

Fig. 2 - Average annual yield of the selected bond indices and the aggregate value of the pension funds from 2005 to 2015. Source: The Organisation for Economic Co-operation and Development data 
The first model equation is as follows:

$P F=2.22005+0.228467 S P B+0.115595 M L+0.742753 B B+1.57153 \mathrm{BW}$.

Tab. 2 - Summary of the second regression model. Source: own elaboration

\begin{tabular}{|l|r|r|r|r|c|}
\hline Indicator & Coefficient & \multicolumn{1}{c|}{$\begin{array}{c}\text { Standard } \\
\text { Error }\end{array}$} & t-test statistics & \multicolumn{1}{c|}{ p-value } & $\begin{array}{c}\text { Statistical } \\
\text { Significance }\end{array}$ \\
\hline $\begin{array}{l}\text { constant } \\
\text { value }\end{array}$ & 2.22005 & 0.718818 & 3.0885 & 0.00203 & $* *$ \\
\hline SPB & 0.228467 & 0.0178908 & 12.7701 & $<0.00001$ & $* * *$ \\
\hline ML & 0.115595 & 0.00726516 & 15.9109 & $<0.00001$ & $* * *$ \\
\hline BB & 0.742735 & 0.0157258 & 47.2304 & $<0.00001$ & $* * *$ \\
\hline BW & 1.57153 & 0.0126801 & 123.9368 & $<0.00001$ & $* * *$ \\
\hline
\end{tabular}

Legend - statistical significance: ${ }^{*}-(0.05 \dashv, \vdash 0.01) ;^{* *}-(0.01 \dashv, \vdash 0.001) ;^{* * *}-(0.001 \dashv, \vdash 0)$.

The above stated figures represent 2,604 measurements over a period from 2008 to 2015. Based on the descriptive statistics data, we can confirm the presumed assumptions of the second regression model. The coefficients of all the investigated variables bear positive values. This demonstrates a statistically positive relationship between the development of the benchmarks of the bond market and an average recovery of the pension funds in the Organisation for Economic Co-operation and Development member countries. The highest estimated regression coefficient is related to the Big World Index; the lowest one to the Bank of America Merrill Lynch Index, with the ratio roughly at the level of fourteen. This demonstrates a very high range of influence of the involved independent variables on the pension funds variable. Is should be noted that the constant value is approximately a quarter higher than the maximum estimated regression coefficient of the independent variables.

An analysis of the aggregated data was carried out to interpret the t-test outcome for each individual variable. The critical value of the confidence level $\alpha=0.05$ in this case is the interval $\langle-1.96,1.96\rangle$. The Standard \& Poor's 500 Bond Index reached a value of 12.7701 , which is higher than a critical level. The second variable, the Bank of America Merrill Lynch Index, was at the level of 15.9109. The third indicator of the Bloomberg Barclays US Aggregate Bond Index stood at 47.2304 and finally, the Big World Index reached the value of 123.9368. These results show all the involved variables as above a critical level. Based on the collected data, it can be concluded that according to the results of the t-test, the zero hypothesis $\mathrm{H}_{0}$ for all the studied variables is rejected. This outcome expresses a statistically significant diversity.

From the point of view of statistical significance of the individual variables, it must be noted that all the contained indicators reach the p-values below a confidence level of 0.05 . This results in the finding that all the variables are statistically significant and their regression coefficients have been declared true. Basically, the zero hypothesis $\mathrm{H}_{0}$ stating that all the estimated regression coefficients are at the level of zero is rejected, i.e. the results of the investigation are verified.

The coefficient of determination $\mathrm{R}^{2}$ of the second model achieves the relatively high level of 0.9787. An interpretation of the achieved result indicates that the proposed model explains more 
than $97 \%$ of the variability of the dependent variable expressing the pension funds. The adjusted coefficient of determination $\mathrm{R}^{2} 0.9786$ also reaches a level which may be considered very high. These values state that the model is economically significant.

To end the interpretation of the second model, it is also necessary to assess the value of the F-test carried out in the model, which reached the level of 29,792.99. The critical value for this model is the level of 2.75297 . Therefore, with a reference to the associated testing of the statistical significance of the coefficients within the regression model, it can be concluded that the independent variables are jointly statistically significant.

\section{Summary}

Based on the above mentioned econometric interpretation, it can be confirmed that there is a statistically significant positive correlation between the development of bond market indices and the appreciation of the pension portfolio management of the asset management companies within the Organisation for Economic Co-operation and Development member countries. In practice, this result indicates that pension funds are significantly correlated with the main component used by most portfolio managers, which is currently fixed income securities. The dependence achieved is even stronger than that of the stock indices.

The analysis shows that the performance of the pension funds is correlated with a number of the economic indicators examined. For the future of the pension system, in the context of shifting a higher level of responsibility for financial well-being in old age, it is necessary to take measures in order to increase the net income of system participants from the ongoing funded system. From this perspective, the main obstacle to the long-term macroeconomic environment of low interest rates, which, together with the unconventional measures taken by central banks, pushes the yield curve of bond assets. Therefore, in the context of existing trends, a consistent co-operation regulator and pension administrator are important in order to streamline the process of investing and managing pension savings with an emphasis on savers' interests.

\section{CONCLUSION}

Pension funds play a crucial role not only in the financial market, but also in the provision of the pension income. For this reason, attention needs to be devoted to analysing the effectiveness of the functioning of pension funds in a more prudent way than to the other financial market investments. In addition to the overall economic consequences, the inability of the pension managers to recover accumulated funds may become a very important social issue for the general population. Investing in pension funds cannot be confidently assessed against other commercial investment options.

In the majority of developed countries, but also in emerging economies, there is a trend towards an increasing share of pension funds in the pension systems. As a result of demographic developments, a further strengthening of responsibility for financial well-being at an old age will be observed in many countries in the future. A major challenge for pension administrators as well as for the pension investment regulator will be to ensure adequate retirement compensation for the widest masses of the population. 
In this paper, we have tried to assess and interpret the impact of certain variables on the overall performance of the pension funds among the member countries of the Organisation for Economic Co-operation and Development. Considering the relationship between the performance of the pension fund and the ratio of assets under management to the gross domestic product, an average pension size can be determined according to the different types of pension system management. The key points that should be taken into account in the process of assessing the impact of the relevant factors to the pension manager measuring the investment portfolio are specific ways of financing the pension unit, the share of foreign investment development, along with characteristic national regulations.

From the pension fund manager's point of view, it is a big challenge to manage the ideal portfolio composition and to generate competitive returns while ensuring reasonable caution when investing in accordance with regulatory requirements as well as client needs. In this context, the considerations outlined above are therefore very important for the consistent maintenance of the pension fund's status and its actual implementation. These include, in particular, the retention of the structure of assets regarding the pension fund's statute, which represents the growth, balance or conservative characteristics of the managed portfolio.

\section{Acknowledgment}

This contribution is the result for the project implementation Creating excellence in economic research department for addressing the challenges of civilization in the 21th century (ITMS 26240120032) supported by the Research \& Development Operational Programme funded by the ERDF the project VEGA (1/0009/17) "The making of the Capital union in Europe and its impact on individual member counties".

\section{References}

1. Alda, M. (2017). The relationship between pension funds and the stock market: Does the aging population of Europe affect it? International Review of Financial Analysis, 49, January 2017, 83-97. https://doi.org/10.1016/j.irfa.2016.12.008.

2. Androniceanu, A. (2017). The three-dimensional approach of Total Quality Management, an essential strategic option for business excellence. Amfiteatru Economic, 19(44), 61-78.

3. Bajtelsmit, V. (2015). Investment Fundamentals. Chichester: John Wiley \& Sons.

4. Bartram, S. M. (2016). Corporate post-retirement benefit plans and leverage. Review of Finance, 20 (2), 575-629. https://doi.org/10.1093/rof/rfv021.

5. Clements, B., Eich, F., \& Gupta, S. (2014). Equitable and Sustainable Pensions, Washington: Interantional Monetaty Fund.

6. De Hann, L. (2016). Recovery measures of underfunded pension funds: higher contributions, no indexation or pension cuts? Journal of Pension Economics and Finance, 17 (4), 437-468, https://doi.org/10.1017/S1474747216000287.

7. Bütler, M. (2002). The political feasibility of pension reform options: the case of Switzerland. Journal of Public Economics, 75(3), 389-416.

8. Devolder, P., Janssen, J., \& Manca, R. (2013). Stochastic Methods for Pension Funds. Chichester: John Wiley \& Sons.

9. Fabuš, M. (2017). Current development of business environment in Slovakia and Czech Republic. Entrepreneurship and Sustainability Issues, 5 (1), 127-137. https://doi.org/10.9770/ jesi.2017.5.1(10). 
10. Farias, P. (2017). Determinants of perceived and actual knowledge of commission paid by contributors in the pension funds industry. BRQ Business Research Quartery, 20 (1), 18-27. https://doi.org/10.1016/j.brq.2016.09.001.

11. Gavurova, B., Belas, J., Kocisova, K., Dapkus, R., \& Bartkute, R. (2017). Revenueand Cost Efficiency of Banking Sectors in the European Union Countries: Do they Depend on Size, Location or Crisis Period? Transformations in Business \& Economics, 16(2), 124-146.

12. Gruber, J. (2012). Public Finance and Public Policy. London: Worth Publishers.

13. Hainaut. (2014). Impulse control of pension fund contributions, in a regime switching economy. European Journal of Operational Research, 239 (3), 810-819. https://doi.org/10.1016/ j.ejor.2014.06.016.

14. Hertrich, C. (2013). Asset Allocation Considerations for Pension Insurance Funds. Stuttgart: Springer Gabler.

15. Mačí, J., \& Valentová Hovorková, V. (2017). Loan versus Bond Financing of Czech Companies and the influence of the Global Recession. Journal of Competitiveness, 9(1), 72-88. https://doi.org/10.7441/joc.2017.01.05.

16. Mitchel, O. S., Maurer, R., \& Orszag, J. M. (2016). Retirement System Risk. Management: Implications of the New Regulatory Order. Oxford: Oxford University Press.

17. Ohanyan G., \& Androniceanu, A. (2017). Evaluation of IMF program effects on employment in the EU. Acta Oeconomica, 67(3), 311-332. https://doi.org/10.1556/032.2017.6 7.3.2

18. Papik, M. (2017). Composition of equity and mixed pension funds in Slovakia. Oeconomia Copernicana, 8(1), 51-64. https://doi.org/10.24136/oc.v8i1.4.

19. Rimashevskaya, N., Malysheva, M., \& Pisklakova-Parker, M. (2017). Utilization of labour resources through matching professional and famility roles. Entrepreneurship and Sustainability Issues, 5(1), 138-149. https://doi.org/10.9770/jesi.2017.5.1(11)

20. Sinicakova, M., \& Gavurova, B. (2017). Single Monetary Policy versus Macroeconomic Fundamentals in Slovakia. Ekonomicky casopis, 2017, 65(2), 158-172.

21. Sinicakova, M., Sulikova, V., \& Gavurova, B. (2017). Twin Defiits Threat in the European Union. E \& M Ekonomie a Management, 20(1), 144-156. https://doi.org/10.15240/ $\mathrm{tul} / 001 / 2017-1-010$.

22. Schulmerich, M., Leporcher Y., \& Eu, C. (2014). Applied Asset and Risk Managment: A Guide to Modern Portfolio Management and Behavior-Driven Markets. Stuttgart: Springer Gabler.

23. Sun, Y., Aw., G., Loxton, R., Teo, K. L. (2017). Chance-constrained optimization for pension fund portfolios in the presence of default risk. European Journal of Operational Research, 256 (1), 205-214. https://doi.org/10.1016/j.ejor.2016.06.019.

24. Tao, Q., Chen, C., Lu, R., \& Zhang, T. (2017). Underfunding or distress? An analysis of corporate pension underfunding and the cross-section of expected stock returns. International Review of Economics and Finance, 48 (1), 116-133. https://doi.org/10.1016/ j.iref.2016.11.009.

25. Thomas, A., Spataro, L., \& Mathew, N. (2014). Pension funds and stock market volatility: An empirical analysis of OECD countries. Journal of Financial Stability, 11 (1), 92-103. https://doi.org/10.1016/j.jfs.2014.01.001. 
26. Vassallo, J. M., Rangel, T., De Los Angeles, B. M., \& Bueno, P. C. (2017). The Europe 2020 Project Bond Initiative: an alternative to finance infrastructure in Europe. Tecbnological and Economic Development of Economy, 24 (1), 229-252, https://doi.org/10.3846/20294913.2016.12 09251.

27. Wang, H., Koo, B., \& O'Hare, C. (2016). Retirement planning in the light of changing demographics. Economic Modelling, 52 (1), 749-763, https://doi.org/10.1016/ j.econmod.2015.10.014.

28. Wiafe, O. K., Basu, A. K., \& Chen, J. (2017). The effects of age pension on retirement drawdown choices. Finance Research Letters, 20 (1), 81-87. https://doi.org/10.1016/ j.frl.2016.09.019.

29. Yao, H., Lai, Y., Ma, Q., \& Jian, M. (2014). Asset allocation for a DC pension fund with stochastic income and mortality risk: A multi-period mean-variance framework. Insurance: Mathematics and Economics,. 54 (1), 84-92, https://doi.org/10.1016/j.insmatheco.2013.10.016.

30. Vychytilová, J. (2015). Linkages among U.S. Treasury Bond Yields, Commodity Futures and Stock Market Implied Volatility: New Nonparametric Evidence. Journal of Competitiveness, 7(3), 143-158. https://doi.org/10.7441/joc.2015.03.10.

31. Ząbkowicz, A. (2016). A paradox of reforming pensions in Poland, Equilibrium. Quarterly Journal of Economics and Economic Policy, 11(3), 585-602. https://doi.org/10.12775/ EQUIL.2016.026.

32. Zou, N., Suo, Z., \& Li, C. (2016). Interactive relationship between rural pension insurance and economic growth based on VAR model. Revista Tecnica de la Facultad de Ingenieria Universidad del Zulia. 39 (10), 287-292. https://doi.org/10.21311/001.39.10.34.

\section{Contact information}

Prof. Ing. Bozena Chovancova, PhD.

University of Economics in Bratislava

Faculty of National Economy

Department of Banking and International Finance

Slovak Republic

E-mail:bozena.chovancova@euba.sk

Ing. Jaroslav Hudcovsky, PbD.

University of Economics in Bratislava

Faculty of National Economy

Department of Banking and International Finance

Slovak Republic

E-mail: hudcovsky.jaroslav@gmail.com

Ing. Anna Kotaskova

Pan-European University in Bratislava

Faculty of Economics and Business

Slovak Republic

E-mail:anna.kotaskova@gmail.com 